\title{
CENY CUKRU W POLSCE I ICH DETERMINANTY
}

\begin{abstract}
Abstrakt
Rynek cukru w UE należy do najbardziej uregulowanych rynków żywnościowych, a podstawe regulacji stanowia kwoty produkcyjne i regulacje handlu zagranicznego. Równocześnie ogniwa łańcucha marketingowego charakteryzują się zróżnicowanym stopniem koncentracji, co przy silnej ochronie rynku stwarza potencjalne warunki dla praktyk monopolistycznych oraz uzyskiwania tzw. marż monopolistycznych. W tym kontekście celem opracowania było empiryczna ocena zmian cen cukru w Polsce oraz wskazanie ich determinant. Badania oparto na miesięcznych cenach cukru w Polsce, UE $i$ w świecie, w latach 2000-2014. Do oceny prawidtowości wykorzystano modele szeregów czasowych. Przeprowadzone badania wskazuja, że produkcja i ceny cukru w Polsce i UE sq w przeważajacym stopniu uwarunkowane systemem regulacji rynkowych, zaś przeprowadzona reforma rynku cukru w niewielkim stopniu wptynęła na wzrost powiąań cen w UE z cenami światowymi. Równocześnie mamy do czynienia z silnymi współzależnościami między cenami detalicznymi i cenami zbytu w Polsce, które moga przybierać charakter zależności nieliniowych.
\end{abstract}

Słowa kluczowe: rynek cukru, ceny, łańcuch marketingowy, transmisja cen, model ekonometryczny, relacje cenowe

\section{Wstęp}

Cukier jest obecnie podstawowym środkiem słodzącym w gospodarce żywnościowej, pomimo rozwoju rynku innych środków słodzących (np. syropów skrobiowych). Branża cukrownicza ma duże znaczenie gospodarcze, a w wielu krajach uznawana jest za strategiczny dział sektora rolno-spożywczego. Jest to jeden $\mathrm{z}$ argumentów uzasadniających potrzebę analizowania zmian mechanizmów leżących u podstaw zmian cen cukru. 
Produkcja cukru od zawsze była wspierana protekcjonistyczną polityką rynkową. Rynek cukru w większości krajów należy do najsilniej regulowanych rynków żywnościowych, a przemysł cukrowniczy charakteryzuje się silnie skoncentrowaną strukturą podmiotową. Niewielka liczba producentów wytwarzających homogeniczny produkt powoduje, że rynek ma strukturę klasycznego oligopolu. Liberalizacja światowego handlu produktami rolno-spożywczymi w latach 1995-2000, procesy globalizacyjne, reforma regulacji w latach 2006-2010 oraz liczne porozumienia bilateralne z krajami rozwijającymi się gospodarczo spowodowały, że unijny i krajowy rynek cukru w coraz większym stopniu są powiązane z rynkiem światowym (Szajner i Hryszko, 2013).

W nawiązaniu do powyższych sformułowań, celem opracowania jest przedstawienie mechanizmów kształtowania się cen w sektorze cukrowniczym oraz empiryczna analiza tendencji cen producenta i cen detalicznych w Polsce oraz ich współzależności z cenami w UE i w świecie. Istotna jest próba odpowiedzi na pytanie dotyczące roli polityki ekonomicznej, w tym reformy rynku cukru w procesie kształtowania się cen w Polsce i w UE. W pierwszej części opracowania zawarto opis uwarunkowań ekonomicznych funkcjonowania rynku cukru, w drugiej zaś przedstawiono wyniki badań empirycznych w zakresie kształtowania się cen cukru w łańcuchu marketingowym oraz w ujęciu przestrzennym (międzynarodowym).

\section{Instytucjonalne i rynkowe determinanty cen cukru}

Cukier jest zaliczany do produktów, które odegrały istotną rolę w gospodarczym rozwoju świata. Dotyczyło to zmian w rolnictwie, przemyśle spożywczym, handlu zagranicznym oraz struktury popytu na żywność. Trzcina cukrowa jest zaliczana do roślin, które zmieniły oblicze świata (Hobhouse, 2001). Uprawa trzciny cukrowej ma wielowiekową tradycję, ale światowy i europejski rynek cukru zaczął kształtować się w XVII w., kiedy do Europy importowano duże ilości trzcinowego cukru (Łuczak, 1981). Cukrownictwo bazujące na burakach cukrowych rozwinęło się w Europie w XIX w., a na światowym rynku zaznaczyła się trwająca do dziś konkurencja między cukrem trzcinowym i buraczanym.

W Polsce cukrownictwo ma długą historię, gdyż pierwsza w Europie cukrownia przetwarzająca buraki cukrowe powstała w 1801 r. na Dolnym Śląsku. Dynamiczny rozwój sektora nastąpił w latach międzywojennych, czemu sprzyjała ustawowa regulacja rynku. W gospodarce planowanej centralnie cukrownictwo zaliczono do strategicznych działów gospodarki i przemysł cukrowniczy został przejęty pod państwowy zarząd. Monopol państwa eliminował konkurencję między cukrowniami, a nieefektywność sektora (rynku) wyrażały okresowe niedobry podaży, które próbowano rozwiązać systemem reglamentacji i urzędowymi cenami (Wykrętowicz, 1997). W okresie przemian polityczno-gospodarczych lat 90. XX wieku cukrownictwo przeszło proces głębokich przemian 
własnościowych, strukturalnych i modernizacyjnych, w którym można wyróżnić kilka etapów. W pierwszym okresie miały miejsce przekształcenia własnościowe oraz wprowadzono system regulacji rynkowych. Kolejnym etapem była integracja z UE i przejęcie unijnego systemu regulacji rynku, który w latach 2006-2010 został zreformowany. W wyniku restrukturyzacji liczba cukrowni zmniejszyła się z 76 w 2001 r. do 18 w latach 2009-2015 r., funkcjonujących w strukturach czterech koncernów. Potencjał produkcyjny przemysłu cukrowniczego wynosi ok. 2 mln ton i jest nieznaczenie mniejszy niż w latach 90. XX w., gdyż produkcja cukru w przeliczeniu na zakład wzrosła ponad pięciokrotnie do 110 tys. ton (Szajner i Hryszko, 2013).

Łańcuch marketingowy na rynku cukru jest złożony, co wynika zarówno $\mathrm{z}$ cech cukru jako produktu konsumpcyjnego, jak i stosowanych regulacji rynkowych. W Polsce cukier jest środkiem słodzącym wykorzystywanym w przemyśle spożywczym, gospodarstwach domowych i innych działach gospodarki. W rezultacie mogą występować bardzo zróżnicowane systemy dystrybucji, a tym samym dłuższe lub krótsze łańcuchy marketingowe, determinujące proces transmisji cen. Początek łańcucha dostaw stanowi uprawa buraków cukrowych, przetwarzanych w przemyśle cukrowniczym w trwającej ok. 120 dób kampanii. Stronę podażową uzupełnia import cukru białego, który jest przeznaczany do konsumpcji, oraz import cukru surowego, który jest poddawany procesowi rafinacji. W dystrybucji cukru z przemysłu cukrowniczego wyróżnia się handel hurtowy, przemysł spożywczy (rozumiany jako działy wtórnego przetwórstwa żywności) oraz eksport. Przemysł spożywczy oraz handel hurtowy mogą nabywać cukier biały także z importu, a sprzyja temu swobodny przepływ towarów na unijnym rynku oraz preferencyjne kontyngenty importowe przyznawane krajom trzecim. Ostatni etap dystrybucji stanowi handel detaliczny, który oferuje cukier gospodarstwom domowym, ale również słodzone cukrem artykuły spożywcze (rys. 1). Ceny przetworzonych artykułów spożywczych zawierających cukier nie są przedmiotem badań prowadzonych przez autorów na potrzeby niniejszego opracowania.

Ceny cukru w Polsce są wynikiem oddziaływania szerokiego spektrum czynników, zarówno o charakterze rynkowym, jak i instytucjonalnym. Do czynników o charakterze rynkowym należy zaliczyć relacje podaży (produkcję, import) i popytu (zużycie, eksport), w których ze względu na postępującą otwartość rynków należy uwzględnić sytuację na rynkach zewnętrznych. Do czynników o charakterze rynkowym należy zaliczyć także oligopolistyczną strukturę rynku, w tym w szczególności model funkcjonowania oligopolu. Siła i kierunki oddziaływania wymienionych rynkowych determinantów jest w znacznym stopniu warunkowana przez politykę rynkową.

Rynek jest fundamentalną kategorią mikroekonomii i jest definiowany jako zespół mechanizmów prowadzący do tego, że decyzje konsumentów i producentów zostają wzajemnie uzgodnione za pośrednictwem cen (Rembisz i Kowalski, 2005). Kluczową rolę w przytoczonej definicji odgrywają relacje strony 
podażowej i popytowej, które wyrażają się w cenach. Definiowanie branży jako grupy producentów i handlowców skutkuje tym, że jest ona utożsamiana przede wszystkim z podażową stroną rynku (Porter, 1992; Png i Lehman, 2013). Badania rynkowe, w tym zwłaszcza analiza cen, stanowią podstawę ekonomii branży (sektora). Wynika to z czterech podstawowych funkcji rynku w gospodarce: równoważącej, informacyjnej, dochodotwórczej i efektywnościowej (Rembisz i Kowalski, 2005).

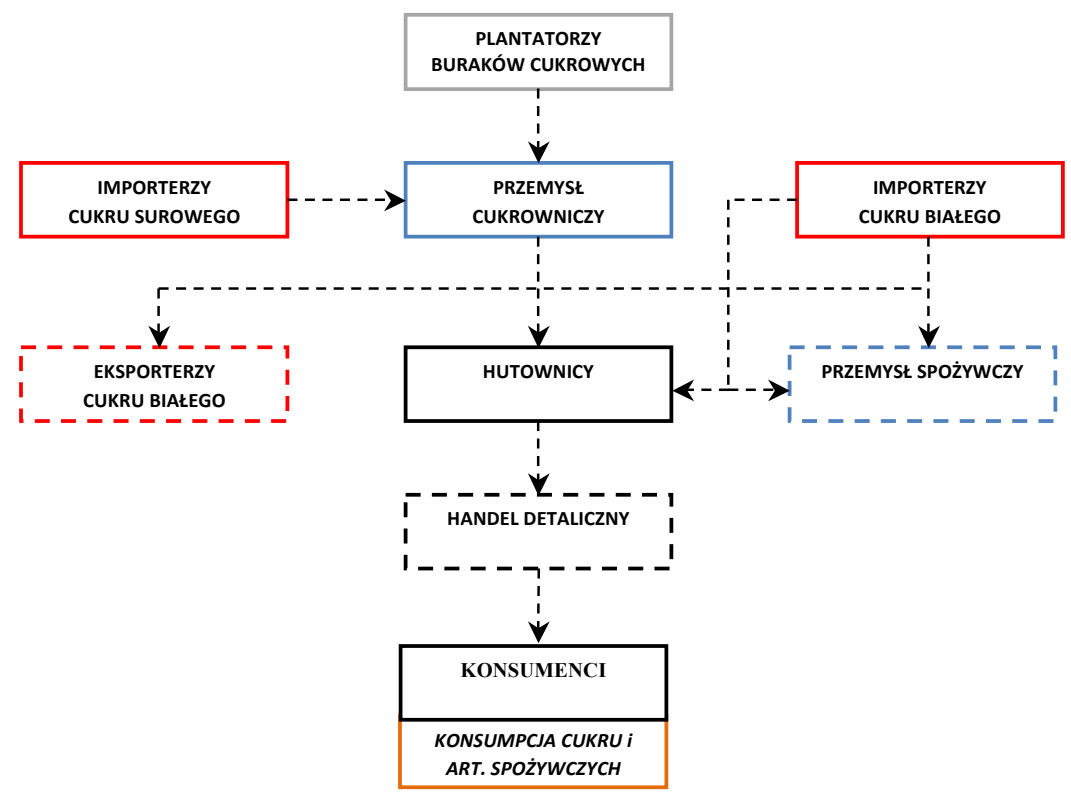

Rys. 1. Schemat łańcucha marketingowego cukru.

Źródło: Opracowanie własne.

W gospodarce rynkowej ceny są przede wszystkim wypadkową gry popytu i podaży. W rzeczywistości gospodarczej ceny na poszczególnych etapach łańcucha marketingowego, w tym także w sektorze rolno-żywnościowym, są wynikiem bardzo wielu czynników. Powodem tego jest bardzo często podnoszona w literaturze nieefektywność rynku, w tym także w obszarze wyznaczania cen (Kamińska i Kątowski, 2006). Nieefektywność rynku stanowi podstawę uzasadnienia do wprowadzania wszelkich instrumentów polityki rynkowej. Jednym z głównych celów WPR, realizowanym poprzez Wspólną Organizację Rynków, jest „stabilizacja rynków”. Proces kształtowania się cen stanowi obszar zainteresowań polityki regulacyjnej zarówno ze względów teoretycznych, jak i czysto utylitarnych (Figiel, 2002; Peltzman, 2000; Rembeza i Seremak-Bulge, 2006). 
Rynek cukru w Polsce jest klasycznym oligopolem, gdyż czterej producenci wytwarzający homogeniczny produkt kojarzeni są z dużą liczbą konsumentów. W teorii funkcjonowania struktur oligopolistycznych wyróżnia się dwie grupy modeli: zmowy (np. kartel, trast, syndykat) oraz interakcje między uczestnikami. Wszelkie zmowy są prawnie zabronione, niszczą bowiem konkurencję rynkową, co jest niekorzystne dla konsumentów ${ }^{1}$. Interakcje uczestników oligopolu w ujęciu teoretycznym odwołują się do teorii gier. Cztery podstawowe formy interakcji uczestników oligopolu to: model Steckelberga, przywództwo cenowe, model Caurnota i model Bertranda (Varian, 2010).

W Polsce funkcjonowanie oligopolu cukrowniczego determinowane jest przez system regulacji rynku. Kwoty produkcyjne są przyznawane producentom, a zatem istnieją niewielkie możliwości konkurowania wolumenem produkcji, ponadto producenci dysponują pełną informacją na temat wielkości limitów produkcyjnych przyznanych konkurentom. Różnica w poziomie unijnych i światowych cen oraz restrykcyjne przepisy dotyczące zagospodarowania cukru pozakwotowego powodują, że jego produkcja może być opłacalna wyłącznie w warunkach bardzo wysokich cen światowych. Cukier jest produktem o wystandaryzowanych właściwościach i producenci w niewielkim stopniu mogą realizować strategię konkurencji, polegającą na wyróżnieniu lub koncentrowaniu się na określonej grupie odbiorców. Minimalna cena skupu buraków cukrowych i referencyjna cukru istotnie ograniczają również możliwości konkurowania cenami. Popyt na cukier charakteryzuje się niską cenową elastycznością (Cubbin, 1973; Tangermann, 2012). W warunkach niskiej cenowej elastyczności popytu spadek cen skutkuje spadkiem przychodów (Samuelson i Nordhaus, 2004). W związku z tym funkcjonowanie oligopolu cukrowniczego najbardziej odpowiada modelowi Bertranda, a strategia konkurowania jego uczestników bazuje przede wszystkim na redukcji kosztów (Porter, 1992).

Rynek cukru w UE podlega protekcjonistycznej polityce i jest silnie regulowany. W UE podstawę systemu regulacji rynku cukru stanowi limitowanie podaży (kwoty produkcji) oraz regulacje handlu zagranicznego ${ }^{2}$. W ujęciu teoretycznym kwoty produkcji można intepretować jako sztywną krzywą podaży. Jeżeli kwoty produkcyjne wyznaczono na niższym poziomie od dotychczasowej podaży, to przy stabilnym popycie nastąpi przesunięcie punktu równowagi i wzrost cen (tzw. renta kwotowa) (Bear-Nawrocka i Kiryluk-Dryjska, 2010; Samuelson i Nordhaus, 2004). W wyniku reformy w latach 2006-2010 kwoty produkcyjne zostały zmniejszone i są mniejsze od produkcji i zużycia. Kwota produkcji w UE

\footnotetext{
${ }^{1}$ Ustawa z dnia 16 lutego 2007 r. o ochronie konkurencji i konsumentów, Dz.U. 2007 nr 50 poz. 331. Directive 98/27/EC of The European Parliament and of the Council of 19 May 1998 on injunctions for the protection of consumers' interests (L 166/51 z 11.06.1998).

${ }^{2}$ Rozporządzenie Parlamentu Europejskiego i Rady (UE) NR 1308/2013 z dnia 17 grudnia 2013 r. ustanawiające wspólną organizację rynków produktów rolnych oraz uchylające rozporządzenia Rady (EWG) nr 922/72, (EWG) nr 234/79, (WE) nr 1037/2001 i (WE) nr 1234/2007. (Dz.U. L. 347/671 z 20.12.2013).
} 
wynosi 13,5 mln ton w przeliczeniu na cukier biały, w tym w Polsce 1,4 mln ton. Produkcja cukru w UE waha się w granicach 17,4-19,4 mln ton, w tym w Polsce 1,7-2,0 mln t, a zużycie wykazuje powolną tendencję wzrostową do odpowiednio $18 \mathrm{mln}$ t i $1,7 \mathrm{mln} \mathrm{t}^{3}$. Restrykcyjne regulacje dotyczące zagospodarowania cukru pozakwotowego ${ }^{4}$ oraz limity produkcyjne mniejsze od zużycia powodują, że UE zmuszona jest eksportować duże ilości cukru pozakwotowego i równocześnie importować ok. $5 \mathrm{mln}$ t. W Polsce różnica między zużyciem i kwotową produkcji wynosi ok. 250 tys. t i takie ilości cukru są przedmiotem importu.

Warto zauważyć, że zdecydowana większość rynków nie funkcjonuje w autarkicznych warunkach i w dużym stopniu sytuację podażowo-popytową kształtuje koniunktura na rynkach zewnętrznych. Procesy globalizacji i integracji regionalnej mają ogromny wpływ na funkcjonowanie mechanizmu rynkowego, gdyż rynki lokalne integrują się w rynki regionalne, tworzące następnie globalny rynek. Gospodarczą istotą tych procesów jest znoszenie lub osłabianie państwowych barier granicznych dla rynku (Szymański, 2004; Pietrzak, 2014).

Integracja rynków, rozumiana jako likwidacja barier (np. handlowych, transportowych itp.) powoduje, że podmioty gospodarcze z różnych krajów funkcjonują w zunifikowanych (wspólnych) uwarunkowaniach rynkowych i politycznych. Konsekwencją likwidacji barier na zintegrowanym rynku jest tendencja do wyrównywania się cen homogenicznego dobra, wyrażonych we wspólnej walucie (Pilbeam, 1998). W teorii ekonomii opisane zjawisko określane jest prawem jednej ceny, obecnie podlegającej dwóm rodzajom interpretacji. Pierwsza uznaje prawo jednej ceny za tendencję do ujednolicania się cen podobnych dóbr, postulując jednocześnie odrzucanie jego absolutnej wersji. Druga interpretacja wiąże wspomniane prawo z arbitrażem, który jest uznawany za sprawczą siłę tej teorii (Wejner, 2008). Arbitraż jest definiowany jako łączona transakcja giełdowa kupna i sprzedaży, umożliwiająca uzyskanie zysku bez ponoszenia ryzyka. Istotą arbitrażu jest zauważenie różnicy cen tego samego produktu na różnych rynkach lub na tym samym rynku, ale pod różnymi postaciami. W przypadku, gdy owa różnica jest większa od kosztów transakcyjnych, inwestor kupując produkt na rynku tańszym, a sprzedając na droższym, osiąga zysk, a efektem tego jest wyrównywanie się cen.

W tym kontekście można postawić pytanie o wpływ sytuacji na rynkach światowych na ceny w UE oraz sytuacji popytowo-podażowej we Wspólnocie na ceny w Polsce. Wszak utrzymywanie kwot produkcyjnych jest uzasadnione tylko w przypadku protekcjonistycznej polityki handlu zagranicznego w UE, której podstawę stanowią wysokie cała oraz bariery poza- i parataryfowe. Równocze-

\footnotetext{
${ }^{3}$ Rynek cukru. Stan i perspektywy, (2015), nr 42, IERiGŻ-PIB, ARR, MRiRW, Warszawa.

${ }^{4}$ Cukier pozakwotowy może być eksportowany do krajów trzecich bez refundacji eksportowych. Zużyty na cele niespożywcze (np. przemysł chemiczny, farmaceutyczny), zaliczony na poczet produkcji kwotowej w następnym sezonie (tzw. przeniesienia) lub sprzedany na rynku wewnętrznym, wymaga wniesienia opłat wyrównawczych (ok. $500 \mathrm{EUR} / \mathrm{t})$.
} 
śnie efektywna alokacja na rynku wewnętrznym wymaga ujednolicenia regulacji. Integracja z UE spowodowała, że branża zaczęła funkcjonować na dużym rynku, charakteryzującym się jednolitymi regulacjami oraz nieograniczonymi barierami handlu między krajami członkowskimi. Proces restrukturyzacji sektora obejmował przede wszystkim przekształcenia własnościowe, których podstawę stanowiły inwestycje transnarodowych koncernów (Chechelski, 2008). W wyniku przekształceń własnościowych przemysł cukrowniczy należy do najbardziej ,zglobalizowanych" branż przetwórstwa żywności w Polsce, ponieważ zagraniczne koncerny posiadają ok. $60 \%$ udział w kwocie produkcji. Przyjęcie unijnych regulacji rynkowych w 2004 r. skutkowało wprowadzeniem w Polsce cen urzędowych obejmujących minimalną skupu i cenę interwencyjną cukru (631,9 EUR/t). W rezultacie wystąpiły przesłanki do wyrównywania się cen krajowych i unijnych.

\section{Dane i metody}

W analizach empirycznych wykorzystano miesięczne notowania cen cukru w Polsce, UE i w świecie z lat 2000-2014. Dane ujęto w zł/kg (w razie konieczności przeliczono na złotówki, z wykorzystaniem średniomiesięcznych kursów NBP). Informacje cenowe zbierano z różnych źródeł i obejmują one różne kategorie rynkowe. W przypadku cen polskich analizowano:

- ceny detaliczne cukru białego paczkowanego wg GUS (oznaczenie: detal. paczk),

- ceny zbytu cukru białego paczkowanego wg GUS (zbyt.paczk),

- ceny zbytu cukru białego luzem wg GUS (zbyt.luz lub biały.zbyt.PL).

W przypadku cen europejskich i światowych uwzględniono następujące kategorie:

- światowe ceny cukru białego - notowania kontraktu nr 5 cukru białego w Londynie (oznaczenie: biały.świat);

- średnie ceny cukru białego w UE - od 2006 r. podawane przez KE (tzw. ex-work prices), do 2006 r. oszacowanie własne na podstawie wskaźników cen podawanych przez Eurostat (biały.UE);

- ceny cukru przemysłowego w UE - średnie ceny cukru pozakwotowego w UE podawane przez KE (przemysłowy.UE);

- ceny interwencyjne cukru białego wg KE (biały.int.UE);

- ceny referencyjne cukru białego wg KE (biały.ref.UE);

- negocjowane ceny importowe cukru surowego do UE, ceny CIF dla krajów ACP wg Banku Światowego (surowy.imp.UE).

Analiza empiryczna obejmuje okres od stycznia 2000 r. do grudnia 2014 r. Biorąc pod uwagę istotny wpływ przystąpienia Polski do UE, analizy ekonometryczne przeprowadzono dla skróconej próby, tj. od stycznia $2005 \mathrm{r}$.

$\mathrm{W}$ badaniach empirycznych wykorzystano szereg metod statystycznych, mających na celu sformułowanie wniosków na temat dynamiki cen oraz współzależności między nimi. Do oceny struktury szeregów czasowych wykorzystano 
dwuetapową metodę TRAMO-SEATS. Jest to metoda dekompozycji szeregu czasowego, w której wyodrębnienie komponentów z szeregu czasowego dokonywane jest na podstawie odpowiednio dobranych modeli ARIMA. Pozwoliło to na określenie charakterystyk obserwacji nietypowych oraz istotności wahań sezonowych (Gomez i Maravall, 2001).

Do oceny stacjonarności szeregów czasowych wykorzystano test ADF-GLS, stanowiący modyfikację testu ADF przeprowadzoną przez Elliotta i in. (1996). Jest to dwustopniowa procedura, w której w szeregu danych $y_{t}$ najpierw ujmujemy komponent deterministyczny (stała i trend) z wykorzystaniem uogólnionej metody najmniejszych kwadratów, a później dopiero reszty z tego równania $\left(y_{t}^{d}\right)$ są podstawą testowania za pomocą równania ADF:

$$
\Delta y_{t}^{d}=\rho y_{t-1}^{d}+\sum_{i=1}^{p} \Delta y_{t-p}^{d}+\varepsilon_{t}
$$

gdzie: $\rho, \gamma$ - parametry modelu, $\varepsilon_{t}$, - składnik losowy, $p$ - maksymalne opóźnienie niwelujące autokorelację. Istotnie różna od zera wartość parametru $\rho$ pozwala odrzucić $\mathrm{H} 0$, mówiącą o występowania pierwiastka jednostkowego w szeregu czasowym $y_{t}$.

W celu określenia współzależności między cenami, zarówno w łańcuchu marketingowym jak i w ujęciu międzynarodowym, wykorzystano modele VAR i VECM. Wektorowy model korekty błędem VAR stosowany jest w przypadku zmiennych stacjonarnych (lub sprowadzonych do stacjonarności) i obejmuje zestaw równań, w którym każda ze zmiennych jest wyjaśniana przez swoje przeszłe obserwacje i przeszłe obserwacje pozostałych zmiennych (Kusideł, 2000; Lütkepohl i Krätzig, 2007):

$$
\mathbf{x}_{t}=\mathbf{A}_{0} \mathbf{d}_{t}+\sum_{i=1}^{r} \mathbf{A}_{i} \mathbf{x}_{t-i}+\mathbf{e}_{t}
$$

zaś model VECM stanowi jego przekształcenie umożliwiające uchwycenia zależności długookresowych:

$$
\Delta \mathbf{x}_{t}=\boldsymbol{\Psi}_{0} \mathbf{d}_{t}+\boldsymbol{\Pi} \mathbf{x}_{t-1}+\sum_{i=1}^{r-1} \Pi_{i} \Delta \mathbf{x}_{t-i}+\boldsymbol{\varepsilon}_{t}
$$

gdzie:

$\mathbf{x}_{t}, \Delta \mathbf{x}_{t}-$ to wektory obserwacji na bieżących wartościach zmiennych lub ich przyrostach,

$\boldsymbol{d}_{\boldsymbol{t}}$ - jest wektorem deterministycznych składników równań,

$\mathbf{A}_{0}, \boldsymbol{\Psi}_{0}$ - to macierze parametrów przy zmiennych wektora $\mathbf{d}_{t}$,

$\mathbf{A}_{i} \boldsymbol{\Pi}_{i}$ - to macierze parametrów przy opóźnionych zmiennych wektora $\mathbf{x}_{t}$ lub $\Delta \mathbf{x}_{t}$, gdzie rząd opóźnienia jest równy $r$, zaś $\boldsymbol{\Pi}=\sum_{i=1}^{k} \mathbf{A}_{i}-\mathbf{I}$ a $\boldsymbol{\Pi}_{i}=\sum_{j=i+1}^{k} \mathbf{A}_{j}$, $\mathbf{e}_{t}, \boldsymbol{\varepsilon}_{t}-$ to wektory reszt równań poszczególnych modeli. 
Niestacjonarne szeregi czasowe są skointegrowane, jeśli ich liniowa kombinacja jest stacjonarna $I(0)$. Nosi ona nazwę ścieżki równowagi długookresowej. Macierz $\Pi$ nazywana jest macierzą równowagi długookresowej i składa się z macierzy wektorów kointegracyjnych $\beta$ i macierzy dostosowań do równowagi długookresowej $\alpha$, co można zapisać $\Pi=\alpha \cdot \beta$. $\Pi_{i}$ jest macierzą parametrów krótkookresowych i podobnie jak $A_{i}$ pozwala formułować wnioski odnośnie przyczynowości krótkookresowej (Osińska, 2008).

Do badania kointegracji w procedurze Johansena używa się rzędu macierzy $\Pi$, który jest równy liczbie niezależnych wektorów kointegracyjnych. Ta prawidłowość jest wykorzystana np. w teście śladu Johansena (istota testu wartość własnej L-max jest zbliżona), którego celem jest określenie liczby wektorów kointegracyjnych (Kusideł, 2000):

$$
L R_{\text {trace }}=-T \sum_{i=r+1}^{n} \ln \left(1-\hat{\lambda}_{i}\right),
$$

gdzie: $L R_{\text {trace }}-$ statystyka testowa, $T$ - liczba obserwacji, $\lambda_{i}$ to wartości własne macierzy $\Pi$.

Test śladu służy do testowania hipotezy zerowej, że liczba wektorów kointegrujących jest równa lub mniejsza od $r$. Hipoteza alternatywna zakłada, że ta liczba jest większa od $r$.

\section{Ceny detaliczne a ceny zbytu w Polsce}

Ceny zbytu i ceny detaliczne w Polsce charakteryzują się znaczą zmiennością w czasie (rys. 2a). Obok rosnącego długookresowego trendu mamy do czynienia $\mathrm{z}$ wahaniami o charakterze cyklicznym (cykle 4-letnie). Wahania sezonowe nie odgrywają większego znaczenia - istotna sezonowość występuje tyko w przypadku cen detalicznych (amplituda tylko 3pp). Ceny zbytu nie charakteryzują się statystycznie istotną sezonowości w świetle testów zawartych w procedurze TRAMO-SEATS. Świadczyć to może to tym, że sezonowość jest determinowana popytowo, a nie podażowo.

Na rynku cukru dochodziło do gwałtownych skokowych zmian poziomu cen w roku 2004 i 2011. W 2004 r. ok. 100\% wzrost cen należy przypisać wstąpieniu do UE (szerzej w kolejnym podrozdziale), po którym nastąpiła ok. 20\% korekta in minus. Przejęcie unijnego systemu regulacji rynku skutkowało wprowadzeniem w Polsce cen urzędowych, obejmujących minimalną cenę skupu buraków cukrowych $^{5}$ i ceną interwencyjną cukru $(631,9$ EUR/t). W 2004 r. średnia cena skupu buraków cukrowych była o 50,6\% wyższa niż przed rokiem, a ceny zbytu i detaliczne cukru zwiększyły się o ok. 47\% w porównaniu do 2003 r. Z kolei w 2011 r.

\footnotetext{
${ }^{5}$ W 2004 r. minimalna cena skupu buraków cukrowych o standardowej zawartości cukru 16\% wynosiła: do produkcji cukru kwoty A - 47,67 EUR/t (przeznaczonego na zaopatrzenie rynku wewnętrznego) i cukru kwoty B - 32,43 EUR/t (przeznaczonego na eksport z dopłatami).
} 
gwałtowny wzrost cen detalicznych i cen zbytu cukru paczkowanego był reakcją na małą produkcję w kampanii 2010/2011 oraz znaczny wzrost cen na rynku światowym. Miał on charakter paniki (bańki spekulacyjnej), ponieważ brak było fundamentalnych podstaw do aż takiego zwiększenia cen. Istotnym czynnikiem stymulującym ówczesny wzrost cen była nieadekwatna reakcja indywidualnych konsumentów (gospodarstw domowych), którzy nabywali duże ilości cukru na zapas. Ceny detaliczne w Polsce były wówczas wyższe od cen w sąsiednich krajach (np. Niemczech), pomimo swobodnego dostępu do unijnego rynku, na którym spadek podaży był mniejszy. Co ciekawe, odmienne zachowanie obserwowano w przypadku cen zbytu cukru luzem, przeznaczonego dla odbiorców przemysłowych. Można napisać, że prawdopodobnie mamy do czynienia z efektami progowymi (treshold effects), polegającymi na kumulowaniu informacji w pewnym okresie (bez większych reakcji rynku), a następnie gwałtownej reakcji uczestników rynku, kiedy ilość informacji osiągnie pewien krytyczny poziom. Warto podkreślić, że efekt reformy cukru w UE w 2006 r. jest praktycznie niezauważalny w kształtowaniu się cen, biorąc pod uwagę skalę zmienności szeregów czasowych (rys. 2).

a)

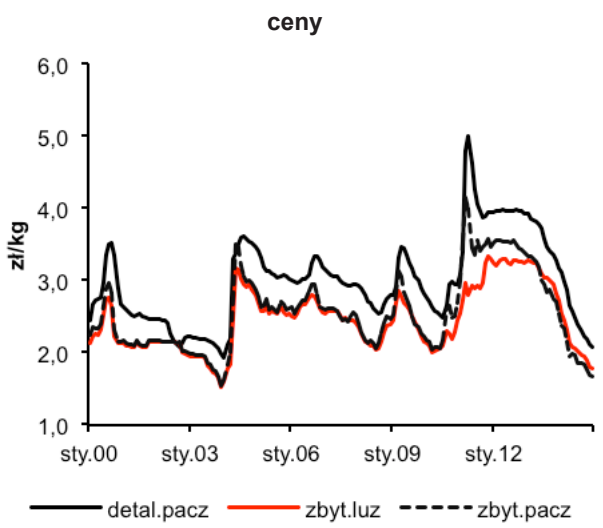

b)

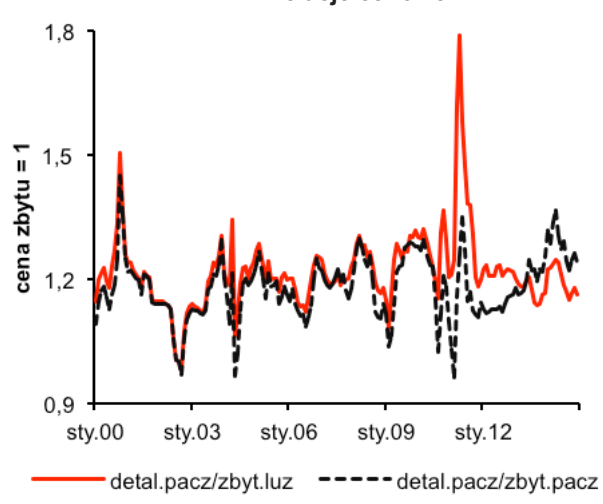

Rys. 2. Kształtowanie się cen detalicznych i cen zbytu cukru w Polsce oraz relacje cen detalicznych do cen zbytu w latach 2000-2014.

Źródło: Opracowanie własne na podstawie danych GUS.

Z rysunku 2a można wnioskować o silnym związku między cenami detalicznymi a cenami zbytu (producenta). Relacje cen detalicznych do cen zbytu w analizowanym okresie kształtują się wokół poziomu około 1,2 (rys. 2b). Odchylenia od wielkości średniej najczęściej nie przekraczają 10\%, jednakże zdarzają się okresy, w których można zaobserwować dosyć nietypowe zachowania cen względem siebie. Szczególnie widoczne jest to w dwóch okresach: w połowie 2000 i w marcu 2011 r., w rezultacie opóźnionych reakcji cen detalicznych 
na zmiany cen producenta. W obydwu przypadkach miało to miejsce w okresie gwałtownych ruchów cen. Warto zauważyć, że notowania cen zbytu cukru luzem i cukru paczkowanego do roku 2010 były silnie skorelowane. Od 2011 r. związek ten znacząco osłabł. Powodem były zmiany w strukturze popytu. Popyt na cukier luzem kreuje wtórne przetwórstwo żywności, które dynamicznie wzrasta, a decyduje o tym, między innymi, rosnący eksport artykułów spożywczych. Równocześnie spożycie cukru $\mathrm{w}$ gospodarstwach domowych wykazywało tendencję spadkową, a wpłynęły na to zmiany modelu konsumpcji oraz malejąca liczba ludności (emigracja, sytuacja demograficzna). Kolejnym powodem mogła być rafinacja trzcinowego cukru surowego w okresie letnim, którą nowe kraje członkowskie mogą prowadzić od $2010 \mathrm{r}$.

W dalszym kroku podjęto próbę oszacowania modeli przedstawiających zależności między cenami detalicznymi (detal.pacz) a cenami producenta (zbyt. pacz). Modele oparto na wartościach logarytmicznych. Z uwagi na zmianę polityki sektorowej w efekcie przystąpienia Polski do UE, analizę przeprowadzono dla okresu od stycznia 2005 roku. Dzięki temu bazowano na jednorodnej próbie. Na początek dokonano analizy właściwości szeregów czasowych z punktu widzenia ich stacjonarności, z wykorzystaniem testu ADF-GLS. Wyniki testu wskazują, że hipotezę zerową o niestacjonarności szeregów czasowych cen zbytu i cen detalicznych cukru należy odrzucić (statystyki testowe wynosiły odpowiednio: -1,13 i -1,42). Dopiero pierwsze różnice okazały się stacjonarne (przy statystykach testowych odpowiednio: $-5,64$ i $-3,27)$.

W przypadku szeregów niestacjonarnych standardowym badaniem jest testowanie występowania zależności długookresowych (tzw. zależności kointegracyjnej). W tym celu zastosowano procedurę Johansena oraz towarzyszące im testy śladu (Trace test) i wartość własnej (L-Max test). Oczekiwano występowania takiej zależności, mając na względzie silne skorelowanie zmiennych oraz brak modyfikacji produktu między ogniwem zbytu a detalu. Z uwagi na to, że testy kointegracji są dosyć wrażliwe na specyfikację modeli, przeprowadzono je w kilku wariantach, dla różnych opóźnień i przy różnych specyfikacjach wyrazu wolnego. Wg kryterium informacyjnego AIC oraz BIC, najlepsze opóźnienie (modelu na poziomach) wynosi 4 , z kolei wg kryterium BIC optymalne opóźnienie wynosi 2 . W naszym przypadku, biorąc pod uwagę przebieg szeregów czasowych cen producenta i cen detalicznych, rozważano modele z ograniczonym i z nieograniczonym wyrazem wolnym przy opóźnieniach od 2 i 4.

W tabeli 1 zawarto wyniki testu śladu (wnioski z testu wartości własnej L-Max były identyczne). W trzech na cztery przypadki wyniki wskazywały na występowanie zależności długookresowej, co sugeruje nam oparcie dalszych badań na modelu VECM. Włączenie do modelu jednej zmiennej sztucznej impulsowej dla obserwacji odstającej (dla marca 2011 roku) powoduje, że w czterech przypadkach odrzucana jest H0 o braku zależności długookresowej (a dokładniej o kointegracji rzędu 0). 
Tabela 1

Test kointegracji między szeregami logarytmów cen zbytu cukru paczkowanego i cen detalicznych - test śladu

\begin{tabular}{cccccc}
\hline \multirow{2}{*}{$\begin{array}{c}\text { Opóźnienia } \\
\text { (dla VAR) }\end{array}$} & Max rząd & \multicolumn{2}{c}{ Ograniczony wyraz wolny } & \multicolumn{2}{c}{ Nieograniczony wyraz wolny } \\
\cline { 3 - 6 } & & statystyka & $\mathrm{p}$ & statystyka & $\mathrm{p}$ \\
\hline \multirow{2}{*}{2} & 0 & 33,866 & 0,000 & 33,392 & 0,000 \\
& 1 & 1,701 & 0,828 & 1,387 & 0,239 \\
4 & 0 & 17,107 & 0,130 & 16,560 & 0,033 \\
& 1 & 2,429 & 0,694 & 1,956 & 0,162
\end{tabular}

Źródło: Opracowanie własne na podstawie danych GUS.

W tabeli 2 przedstawiono oszacowania modeli VECM z nieograniczonym wyrazem wolnym i dwoma opóźnieniami na poziomach zmiennych (na pierwszych różnicach opóźnienie wynosi 1). Wnioski z pozostałych specyfikacji nie różniły się od wybranej. Zmiennych sezonowych nie włączano do modelu, ponieważ żadna z nich nie była statystycznie istotna. Pierwszy model oszacowano bez dodatkowych zmiennych egzogenicznych. Współczynnik beta relacji kointegrującej wynosi 0,87 , wskazując, że $1 \%$ zmianie cen zbytu towarzyszy $0,87 \%$, zmiana cen detalicznych. Dostosowania do relacji długookresowej (EC) występują po stronie cen detalicznych (istotny współczynnik na poziomie $-0,44$ ). Drugi ze współczynników posiada również ujemy znak, co dowodzi, że ceny zbytu nie dostosowują się do relacji długookresowej, można by wręcz napisać, że są źródłem niestabilności. W tym kontekście można wnioskować, że ceny zbytu są egzogeniczne względem cen detalicznych, a tym samym sytuacja podażowa i polityka regulacyjna determinują poziom cen cukru w kraju w długich i średnich okresach. Przyczynowość krótkookresowa w sensie Grangera ma charakter dwustronny (tab. 2).

Warto podkreślić, że model 1 nie spełnia założenia o normalnym rozkładzie składnika resztkowego wskutek występowania wartości odstających (statystyka testu Doornika-Hansena wynosi aż 957,4 ). Jest to pochodną pojawiających się zmian strukturalnych w poszczególnych szeregach czasowych i ich relacjach (rys. 4 i 5), a tym samym wartości nietypowych w przyrostach cen. Również mamy tu do czynienia z autokorelacją reszt w równaniu drugim $(Q 2=21,57)$.

W celu złagodzenia wpływu nieliniowości związanych z nietypowymi obserwacjami w kolejnym modelu (model 2, tab. 2) zdecydowano się wprowadzić nieograniczoną zmienną zerojedynkową dla marca 2011 roku. Tym samym, szacując model na przyrostach częściowo niweluje się wpływ skokowej zmiany cen, jaka miała miejsce w tym okresie. Dzięki temu statystyka testu Doornika-Hansena obniżyła się trzydziestokrotnie (mimo to nie udało się uzyskać rozkładu normalnego reszt modelu, głównie w przypadku równania cen detalicznych) oraz poprawiono właściwości reszt $\mathrm{w}$ zakresie autokorelacji. Wnioski z tego 
modelu są zbieżne z wnioskami z modelu 1. Relacja długookresowa jest praktycznie taka sama. Nieznacznie obniżyły się współczynniki przy relacji kointegrującej EC (głównie w równaniu cen detalicznych).

Tabela 2

Oszacowania modeli VECM

\begin{tabular}{|c|c|c|c|c|c|}
\hline \multicolumn{6}{|c|}{ Model 1} \\
\hline \multicolumn{3}{|c|}{ Zmienna objaśniana: d_1_detal.pacz } & \multicolumn{3}{|c|}{ Zmienna objaśniana: d_1_zbyt.pacz } \\
\hline Zm. objaśniająca & Współczynnik & Stat. t-studenta & Zm. objaśniająca & Współczynnik & Stat. t-studenta \\
\hline const & 0,117 & 5,857 & const & 0,098 & 3,169 \\
\hline d_1_detal.pacz_1 & 0,040 & 0,581 & d_1_detal.pacz_1 & $-0,399$ & $-3,757$ \\
\hline d_1_zbyt.pacz_1 & 0,302 & 3,305 & d_1_zbyt.pacz_1 & 0,353 & 2,474 \\
\hline $\mathrm{EC}$ & $-0,436$ & $-5,946$ & $\mathrm{EC}$ & $-0,374$ & $-3,275$ \\
\hline \multicolumn{6}{|c|}{ Relacja kointegrująca: 1_detal.pacz -0,896*1_zbyt.pacz } \\
\hline \multicolumn{6}{|c|}{ Test Doornika Hansena: $=957,32(\mathrm{p}=0,000)$, Test Ljung-Boxa: $\mathrm{Q} 1=18,25(\mathrm{p}=0,108), \mathrm{Q} 2=21,57(\mathrm{p}=0,043)$} \\
\hline \multicolumn{6}{|c|}{ Model 2} \\
\hline \multicolumn{3}{|c|}{ Zmienna objaśniana: d_1_detal.pacz } & \multicolumn{3}{|c|}{ Zmienna objaśniana: d_1_zbyt.pacz } \\
\hline Zm. objaśniająca & Współczynnik & Stat. t-studenta & Zm. objaśniająca & Współczynnik & Stat. t-studenta \\
\hline const & 0,101 & 9,236 & const & 0,097 & 3,035 \\
\hline d_1_detal.pacz_1 & 0,041 & 1,138 & d_1_detal.pacz_1 & $-0,395$ & $-3,776$ \\
\hline d_1_zbyt.pacz_1 & 0,201 & 4,119 & d_1_zbyt.pacz_1 & 0,309 & 2,185 \\
\hline d.2011.03 & 0,245 & 17,240 & d. 2011.03 & 0,089 & 2,153 \\
\hline $\mathrm{EC}$ & $-0,377$ & $-9,646$ & $\mathrm{EC}$ & $-0,359$ & $-3,172$ \\
\hline
\end{tabular}

Relacja kointegrująca: 1_detal.pacz $-0,886 * 1 \_z b y t . p a c z$

Test Doornika Hansena: = 33,41 (p=0,000), Test Ljung-Boxa: Q1=10,66 ( $\mathrm{p}=0,558), \mathrm{Q}=14,27(\mathrm{p}=0,284)$

Źródło: Opracowanie własne na podstawie danych GUS.

Analiza dekompozycji błędów prognoz przy strukturyzacji powyższych modeli, zakładającej, że ceny detaliczne są pochodną zmian cen zbytu i jest dosyć zbliżona. Wskazuje ona, że w długim okresie ceny zbytu w 75\% (model 1) oraz 90\% (model 2) determinują ceny detaliczne. Różnice między obydwoma modelami sugerują, że dostosowania do równowagi długookresowej prawdopodobnie zależą od skali tej nierównowagi. Jeśli odchylenia od równowagi są niewielkie, wówczas dostosowania są powolne, natomiast gdy skala nierównowagi wzrasta, wówczas szybkość powrotu do niej ulega zwiększeniu. Dokładniejsze rozpoznanie tych mechanizmów możliwe byłoby np. z użyciem modeli progowych TVAR i TVECM. Tutaj jedynie zaprezentowano graficznie ten typ zależności (rys. 3), przyjmując jako podstawę model TAR (Enders i Siklos, 2001). 
Średnia wartość relacji kointegrującej EC w modelu VECM z nieograniczonym wyrazem wolnym wynosi 0,27 (wg modelu 1 , oś pozioma rys. 3 ). Zauważyć można, że dostosowania do relacji długookresowej są nieznaczne w przedziale 0,20-0,35. Siła dostosowań, obrazowana nachyleniem dopasowanych linii (wielomianu trzeciego stopnia oraz regresji lokalnej LOESS) (Cleveland, Devlin i Grosse, 1988) znacząco wzrasta po przekroczeniu powyższych wielkości. Innymi słowy, jeśli odchylenia od długookresowej równowagi nie przekraczają $+/-7 \%$, dostosowania praktycznie nie mają miejsca. Dopiero po przekroczeniu tego poziomu (prawdopodobnie są to koszty menu) uruchamiane są mechanizmy dostosowawcze.

a)

b)
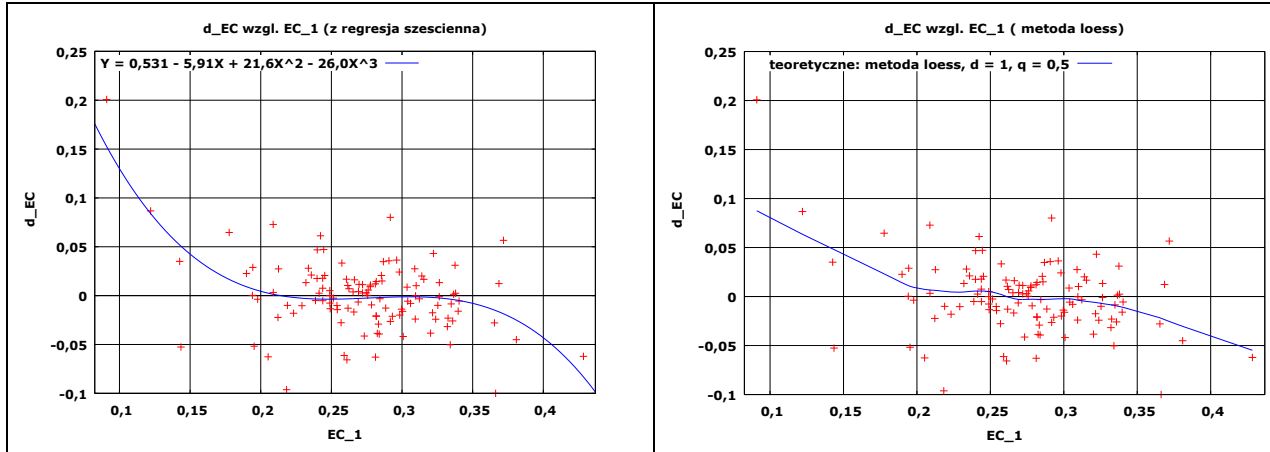

Rys. 3. Dostosowania cen detalicznych i zbytu do równowagi długookresowej.

Źródło: Opracowanie własne na podstawie danych GUS.

\section{Ceny w Polsce a ceny na rynkach zagranicznych}

W świetle rozważań przedstawionych w poprzednim rozdziale, ceny cukru w Polsce warunkowane są głównie czynnikami podażowymi. W niniejszym rozdziale przedstawimy kształtowanie się cen cukru w Polsce na tle cen światowych oraz europejskich, wskazując przy tym wpływ organizacji rynku wspólnotowego w tym zakresie. W pierwszej kolejności odniesiemy się do związków między cenami cukru białego w UE a rynkowymi cenami cukru w świecie. Pobieżna analiza graficzna (rys. 4) wskazuje, że przez wiele lat ceny cukru w UE (biały.UE) kształtowały się znacznie powyżej cen światowych (biały. świat). Wynikało to z silnej ochrony celnej, wysokich cen interwencyjnych (biały.int.UE) oraz kwotowania produkcji i subwencjonowania eksportu cukru. Do roku 2006 ceny rynkowe producentów cukru w UE były powyżej cen interwencyjnych $(631,9$ EUR/t). Można by napisać, że praktycznie do roku 2006, a nawet do roku 2008, nie było żadnej współzależności między cenami we Wspólnocie a cenami światowymi. 


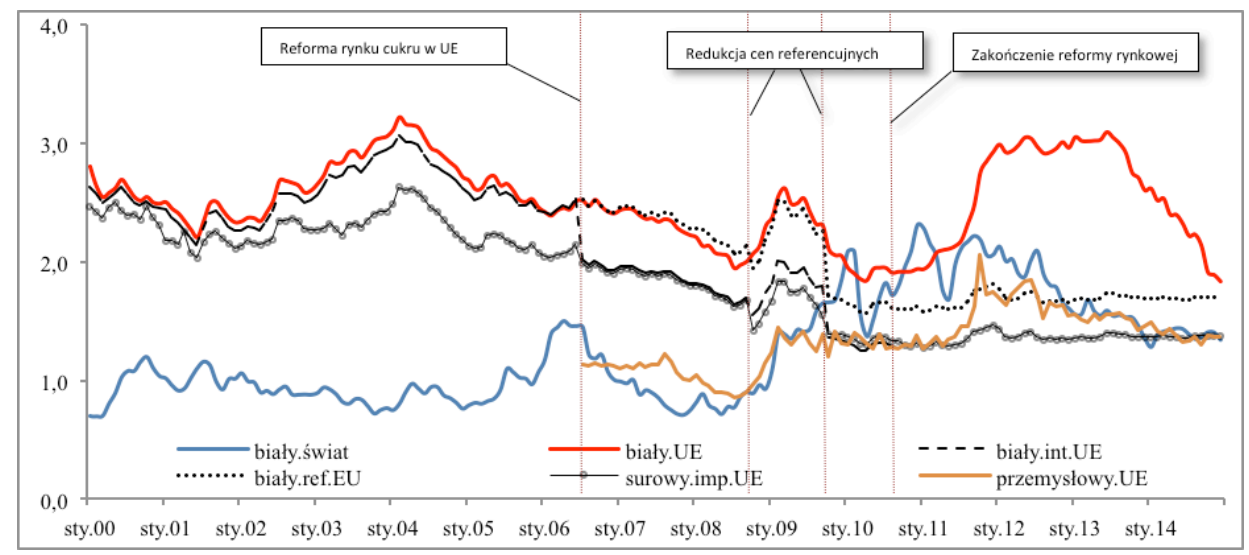

Rys. 4. Ceny producenta cukru w UE i w świecie na tle unijnych cen interwencyjnych, referencyjnych i importowych w latach 2000-2014 (PLN/kg).

Źródło: Opracowanie własne na podstawie danych USDA, Bank Światowy, KE, NBP.

Wraz z reformą rynku cukru w 2006 r. stopniowo znaczenie traciły ceny interwencyjne (zostały obniżone do poziomu zerowego w 2010 r. wraz z zakończeniem zakupów interwencyjnych). W ich miejsce pojawiły się ceny referencyjne (biały.ref.UE), których poziom został dwukrotnie obniżony i obecnie wynosi 404,4 EUR/t. Do momentu zakończenia zakupów interwencyjnych (koniec 2009 r.) ceny rynkowe nie odbiegały znacząco od cen referencyjnych. Od 2010 r. współzależności między cenami rynkowymi cukru w UE a ceną referencyjną nie są już tak silne. Z uwagi na wysokie ceny cukru na rynkach światowych ceny referencyjne w UE w latach 2010-2014 były niższe od cen rynkowych, zaś w latach 2010-2012 nawet niższe od cen światowych.

Wraz z zakończeniem interwencji na rynku cukru pojawiły się przesłanki dla współzależności między cenami cukru białego w UE (biały.UE) i cenami światowymi (biały.świat) (Areté, 2012). Analizy statystyczne nie wykazują skoinegrowania tych zmiennych (brak zależności długookresowych), zarówno dla całej próby, jak i dla różnych podokresów (od 2006 czy od 2010 r.). Testy Johansena również nie pozwalają uznać, iż mamy do czynienia z równowagą długookresową w układzie trzech zmiennych: ceny światowe, ceny UE oraz ceny polskie. Warto podkreślić, że ceny cukru pozakwotowego (przemysłowy.UE) wydają się być bardziej skorelowane z cenami światowymi niż ceny rynkowe cukru białego (kwotowanego). Przy czym związek ten uległ osłabieniu w latach 2010-2011 - wówczas ceny cukru przemysłowego odzwierciedlały przebieg negocjowanych cen cukru surowego z krajów rozwijających się (LDC, ACP). Warto podkreślić, że w latach 2010-2011 ceny światowe były bardzo wysokie - 700-800USD/t, a jednocześnie ceny cukru kwotowego w UE były niskie. 
Ceny negocjowane importowe cukru surowego w UE (surowy.imp.UE) do 2009 r. były skorelowane z cenami na rynku wewnętrznym oraz z cenami interwencyjnymi i referencyjnymi. Od 2010 r. nie widać związku między cenami importowymi a cenami rynkowymi cukru kwotowanego (rys. 4).

Ceny cukru w Polsce do momentu integracji z UE kształtowane były głównie przez uwarunkowania krajowe (podaż i zapasy). Poziom cen krajowych był dwukrotnie wyższy niż cen światowych. Nie zaobserwowano również większych związków między cenami w Polsce (biały.zbyt.PL) a cenami w krajach UE (rys. 5).

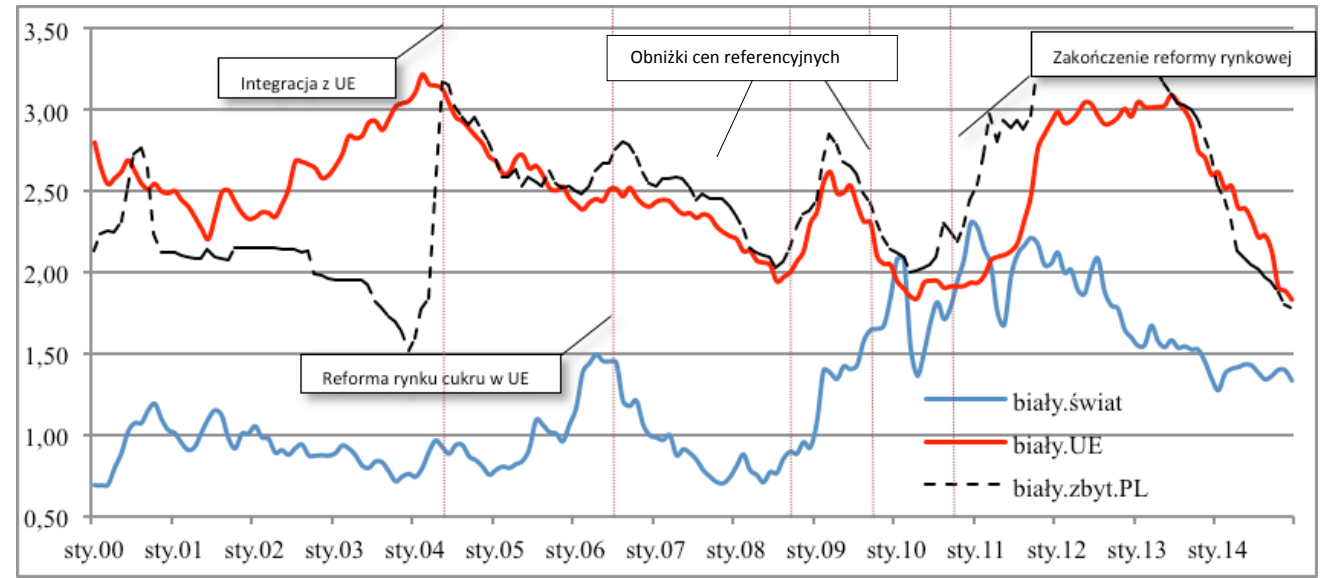

Rys. 5. Ceny zbytu cukru w Polsce na tle cen cukru w UE i cen światowych w latach 2000-2014 (PLN/kg).

Źródło: Opracowanie własne na podstawie danych USDA, Bank Światowy, KE, NBP.

Wraz z integracją w ciągu trzech miesięcy nastąpił dwukrotny wzrost cen zbytu cukru w Polsce, osiągając średni poziom cen we Wspólnocie. Była to znacząca zmiana strukturalna w przebiegu cen. Od objęcia rynku krajowego regulacjami wspólnotowymi, widoczna jest silna zbieżność cen krajowych ze średnimi cenami w UE. Warto zauważyć, że ceny w Polsce były nieznacznie wyższe od cen w UE (aczkolwiek trudno mówić tutaj o porównywalności danych). Dopiero w ostatnim roku relacje te uległy zmianom (rys. 6).

Należy podkreślić, że wzrost cen cukru w Polsce w 2011 r. miał miejsce wcześniej niż w pozostałych krajach UE, co prawdopodobnie wynikało z większej wrażliwości cen krajowych na ceny światowe. Osłabienie związków między cenami w Polsce i cenami w UE można wiązać również z likwidacją interwencji rynkowej (obecnie brak jest cen interwencyjnych i skupu interwencyjnego). 


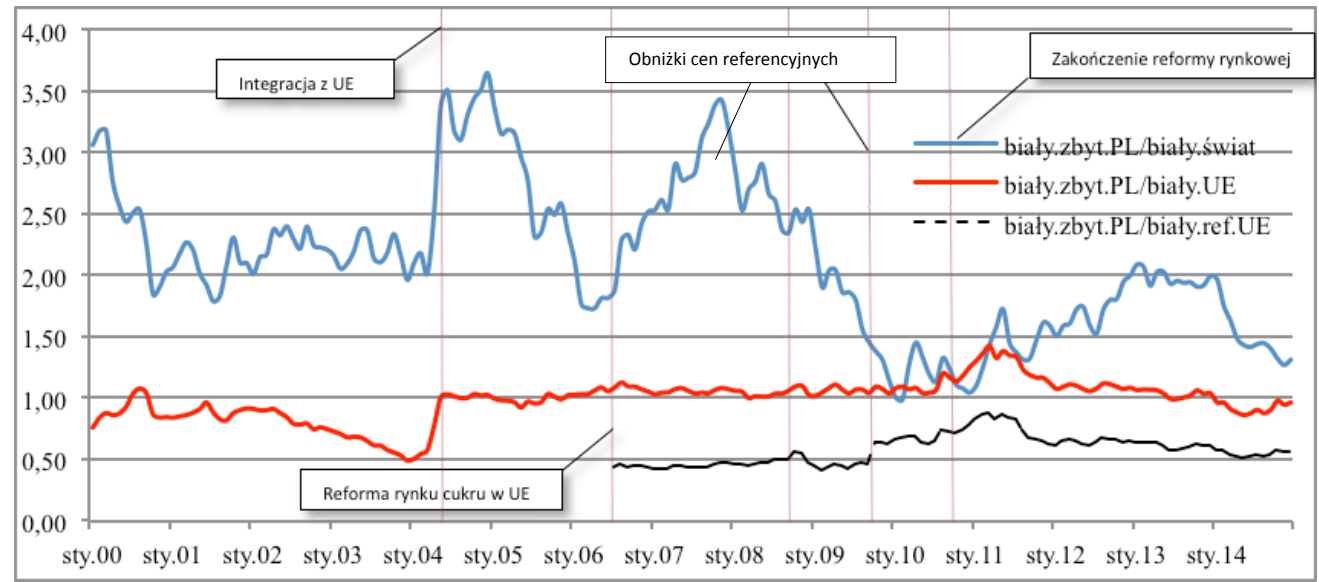

Rys. 6. Relacje zbytu cukru w Polsce do cen światowych i europejskich.

Źródło: Opracowanie własne na podstawie danych GUS, USDA, KE, NBP.

Analizując związki między cenami w Polsce a cenami na rynkach zagranicznych (światowe i unijne), podjęto próbę dokładniejszego określenia natury tych zależności. Badania ograniczono do danych z lat 2005-2014, a więc brano tylko pod uwagę okres po integracji. Analiza ta ma pewną wadę - mianowicie, przy obliczaniu średnich cen w UE uwzględniono również ceny w Polsce (przy czym nie wiadomo, jakie są: formuła ich obliczania, jak również źródła danych stanowiących podstawę ich szacowania). Tym samym mamy tu do czynienia z efektem zagnieżdżenia, jednak autorzy dysponowali tylko takimi danymi.

W pierwszej kolejności dokonano oceny właściwości szeregów czasowych z wykorzystaniem testu ADF-GLS. W jego świetle okazało się, że wszystkie szeregi czasowe są zintegrowane w stopniu pierwszym I(1). Jeśli chodzi o badania dotycząc długookresowych zależności, to wyniki były niejednoznaczne. Jak już z wspomniano wcześniej, wykazano brak zależności długookresowych między cenami światowymi (biały.świat), unijnymi (biały.UE) i polskimi (biały.zbyt.PL). Analizowano zatem tylko układ dwóch zmiennych: ceny polskie i ceny unijne. W prostym modelu Engla-Grangera (zarówno z wyrazem wolnym, jak i bez) nie było podstaw do odrzucenia $\mathrm{H} 0$ mówiącej, że reszty z relacji kointegrującej charakteryzują się pierwiastkiem jednostkowym. Oznacza to brak zależności długookresowej między cenami w Polsce i średnimi cenami w UE. Test Johansena (model bez wyrazu wolnego oraz model z ograniczonym wyrazem wolnym - nieistotnym) wskazuje na jeden wektor kointegrujący. $\mathrm{Z}$ kolei test Johansena, oparty na modelu z nieograniczonym wyrazem wolnym (istotnym), wskazuje na pełen rząd macierzy. 
Jeśli przyjrzymy się relacjom cen w Polsce do cen średnich w UE (rys. 6), to możemy zauważyć, że uległy one zmianom w trakcie członkostwa w UE. Możemy zaobserwować występowanie dwóch reżimów czasowych. Do 2010 r. związek długookresowy był silny (relacje stacjonarne). Po tym okresie, wraz z zakończeniem interwencji, zależności uległy osłabieniu (relacje charakteryzujące się trendem). Zatem trudno jest tutaj zastosować model VECM, który opisywałby charakter dostosowań długookresowych w dwóch różnych reżimach czasowych.

Z tego powodu analizę ograniczono do modelu VAR, oszacowanego na pierwszych przyrostach zmiennych. Oszacowano dwa modele VAR: jeden dla cen polskich i średnich unijnych, w drugim zaś uwzględniono również ceny światowe. W ich świetle można uznać dwustronną przyczynowość w sensie Grangera między cenami w Polsce i w UE. Równocześnie stwierdzono brak jakiejkolwiek (w sensie kierunku i siły) zależności między cenami polskimi i unijnymi a cenami światowymi. Wnioski te nie uległy zmianom przy oszacowaniu modelu dla lat 2011-2014. Wnioskować można zatem, że reforma cukru nie wpłynęła w istotny sposób na wzrost powiązań cen europejskich z cenami światowymi. Powodem jest nadal rozbudowany system regulacji rynkowych (protekcjonistyczna polityka rynkowa), którego podstawą są kwoty produkcyjne oraz silna ochrona celna. Import możliwy (opłacalny) jest jedynie w ramach preferencyjnych kontyngentów. Restrykcyjna polityka podażowa (kwoty produkcyjne), w tym w szczególności w zakresie cukru pozakwotowego, skutkuje tym, że rynek unijny powiązany jest z rynkiem światowym, ale zależności te nie są aż tak wyraziste.

\section{Podsumowanie}

Ogniwa łańcucha marketingowego rynku cukru w Polsce charakteryzują się bardzo zróżnicowanym stopniem koncentracji. Początkowe (producenci rolni) i końcowe (konsumenci) ogniwa charakteryzują się bardzo dużą liczbą uczestników oraz potencjalnie najsłabszą siłą przetargową. Największy poziom koncentracji ma miejsce w przemyśle cukrowniczym, który ma charakter typowej struktury oligopolistycznej. Tak zróżnicowana struktura, przy silnej ochronie rynku, stwarza potencjalne warunki dla praktyk monopolistycznych oraz uzyskiwania tzw. marż monolitycznych.

Produkcja i ceny cukru w Polsce i w Unii Europejskiej w przeważającym stopniu uwarunkowane są systemem regulacji rynkowych. Regulacje obejmują kwoty produkcyjne oraz silną ochronę celną. Przeprowadzona reforma rynku cukru w niewielkim stopniu wpłynęła na wzrost powiązań cen w UE z cenami światowymi w analizowanym okresie. Efektem reformy jest obniżenie relacji cen polskich czy unijnych do cen światowych (zbiegło się to w czasie ze wzrostem światowych cen cukru), a jednocześnie nie jest widoczny wzrost powiazań długo- czy krótkookresowych. 
Ceny zbytu cukru w Polsce od maja 2004 r. powiązane są z cenami w Unii Europejskiej, a ich poziom nie odbiega znacząco od średnich cen we Wspólnocie. Związek ten nieco osłabł wraz zakończeniem reformy rynku cukru w UE, a charakter zależności długookresowej (relacje cenowe) uległ zmianie. Silniejsze współzależności występują między cenami detalicznymi a cenami zbytu w Polsce. Szeregi czasowe tych cen są skointegrowane, a ceny zbytu są egzogeniczne względem cen detalicznych, co wskazuje, że podaż i polityka regulacyjna determinują poziom cen cukru w Polsce w okresach długich i średnich. Równocześnie zauważono wzrost siły dostosowań cen do równowagi długookresowej wraz ze zwiększeniem różnic między cenami w różnych ogniwach łańcucha marketingowego, co wskazuje na prawdopodobieństwo wstępowania tzw. kosztów menu w mechanizmie transmisji pionowej. 


\section{Bibliografia:}

Areté (2012). Study on price transmission in the sugar sector: Draft final report, AGRI-2011EVAL-03, European Commission.

Bear-Nawrocka, A. Kiryluk-Dryjska, E. (2010). Konsekwencje zniesienia kwot mlecznych dla polskiego rolnictwa z uwzględnieniem zróżnicowania regionalnego (wyniki symulacji modelowych). Zagadnienia Ekonomiki Rolnej, $n$ r 2, s. 62-74.

Chechelski, P. (2005). Zasięg procesów globalizacji w Polskim przemyśle cukrowniczym. Komunikaty Ekspertyzy Raporty, nr 506, Warszawa: IERiGŻ-PIB.

Cleveland, W.S., Devlin, S.J., Grosse, E. (1988). Regression By Local Fitting. Journal of Econometrics, $n r$ 37, s. 87-114.

Cubbin, J. (1973). Estimating the Elasticitiess of Demand for Sugar. Journal of Agricultural Economics, vol. 24, issue 2, s. 381-392.

Elliott, G., Rothenberg, T.J., Stock, J.H. (1996). Efficient tests for an autoregressive unit root. Econometrica, vol. 64, issue 4, s. 813-36.

Enders, W., Siklos, P.L. (2001). Cointegration and threshold adjustment. Journal of Business \& Economic Statistics, vol. 19, issue 2, s. 166.

Figiel, S. (2002). Cenowa efektywność rynku towarowego zbóż w Polsce. Olsztyn: Wydawnictwo Uniwersytetu Warmińsko-Mazurskiego.

Gomez, V., Maravall, A. (2001). Seasonal Adjustment and Signal Extraction in Economic Time Series. W: R.S. Tsay (red.) A Course in Time Series Analysis, Nowy Jork: J. Wiley and Son.

Hobhouse, H. (2001). Sechs Pflanzen verändern die Welt: Chinarinde, Zuckerrohr, Tee, Baumwolle, Kartoffel, Kokastrauch. Stuttgart: Klett-Cotta Verlag.

Kamińska, T., Kątowski, T. (2006). Nieefektywność rynku. Teoria i praktyka. Gdańsk: Wydawnictwo Uniwersytetu Gdańskiego.

Köster, U. (2010). Grundzüge der landwirtschaftlichen Marktlehre. München: Verlag Franz Vahlen.

Kusideł, E. (2000). Modelowanie wektorowo-autoregresyjne VAR. Metodologia i zastosowanie w badaniach ekonomicznych. Łódź: Absolwent.

Lütkepohl, H., Krättzig, M. (2007). Applied Time Series Econometrics. Cambridge University Press.

Łuczak, C. (1981). Dzieje cukrownictwa w Polsce. Poznań: Uniwersytet im. Adama Mickiewicza.

Łyszkiewicz, W. (2000). Industrial Organisation. Organizacja rynku i konkurencja. Poznań: WSHiFM.

Osińska, M. (2008). Ekonometryczna analiza zależności przyczynowych. Toruń: Wydawnictwo Naukowe UMK.

Peltzman, S. (2000). Prices rise faster than they fall. Journal of Political Economy, vol. 108, no. 3, s. 466-502.

Png, I., Lehman, D. (2013). Ekonomia menadżerska. Warszawa: Oficyna a Wolters Kluwer Business.

Pietrzak, M. (2014). Problem geograficznego zakresu rynków/sektorów w dobie globalizacji i regionalizacji. Zagadnienia Ekonomiki Rolnej, nr 1, s. 3-21.

Pilbeam, K. (1998). International Finance. New York: Palgrave. 
Porter, M.E. (1992). The competitive advantage of nations. London, Basingstoke: The Macmillan Press Ltd.

Rembeza, J., Seremak Bulge, J. (2006). Asymetria w transmisji cen na rynku mleka i jego przetworów. Zagadnienia Ekonomki Rolnej, nr 3, s. 110-123.

Rembisz, W., Kowalski, A. (2005). Rynek rolny i interwencjonizm a efektywność $i$ sprawiedliwość społeczna. Warszawa: IERiGŻ-PIB.

Samuelson, P.A., Nordhouse, W.D. (2004). Ekonomia, t. 1, Warszawa: PWN.

Scherer, F.M. (1970). Industrial market structure and economic performance. Chicago: Rand McNally College Publishin Company.

Szajner, P., Hryszko, K. (2013). Sytuacja na światowym rynku cukru i jej wpływ na możliwość uprawy buraków cukrowych w Polsce. PW 2011-2014, nr 71, Warszawa: IERiGŻ-PIB.

Szymański, W. (2004). Interesy i sprzeczności globalizacji. Wprowadzenie do ekonomii ery globalizacji. Warszawa: DIFIN.

Tangermann, S. (2012). Preisanstieg am EU-Zuckermarkt: Bestimmunsgründe und Handlungsmöglichkeiten der Marktpolitik. Diskussionspapiere, Nr 1203, Universität Göttingen.

Varian, H.R. (2002). Mikroekonomia. Warszawa: PWN.

Wejner, P. (2008). Parytet siły nabywczej jako wyznacznik realnego kursu walutowego. Ewolucja w kierunku nieliniowych modeli autoregresyjnych. Warszawa: NBP.

Wykrętowicz, S. (1997). Najnowsze dzieje cukrownictwa w Polsce (1944-1998). Poznań: Muzeum Narodowe Rolnictwa i Przemysłu Rolno-Spożywczego w Szraniewie. 
MARIUSZ HAMULCZUK

PIOTR SZAJNER

Institute of Agricultural and Food Economics

- National Research

Warsaw

\section{SUGAR PRICES IN POLAND AND THEIR DETERMINANTS}

\section{Summary}

The sugar market in the EU is among the most regulated food markets in the world. This regulation is based on production quotas and foreign trade regulations. Individual links of the marketing chain are characterised by highly varied degree of concentration. Growers of sugar beets and consumers are very numerous and possibly have the weakest bargaining power. The highest degree of concentration is in the sugar industry, which is a classic oligopoly, because four producers manufacture a homogenous product. Thus differentiated structure, faced with strong market protection, creates potential conditions for monopolistic practices and obtaining the so-called monolithic margins.

Sugar production and prices in Poland and in the EU are largely conditioned by the system of market regulations. The conducted sugar market reform had little effect on the interrelation of the EU prices with the world prices in the analysed period. As a result of the reform, the relations of the Polish or EU prices to the world prices dropped (this coincided with the growth in the world sugar prices) and, at the same time, there is no growth in the long- or short-terms relations. In 2004, the selling prices of sugar in Poland are linked to the EU prices and their level is not highly divergent from the average prices in the Community. These relations weakened slightly along with the end of the reform and the nature of long-term relations changed. Stronger interrelations are between retail and wholesale prices.

Key words: sugar market, prices, marketing chain, price transmission, econometric model, price relations

Zaakceptowano do druku - Accepted for print: 03.12.2015. 